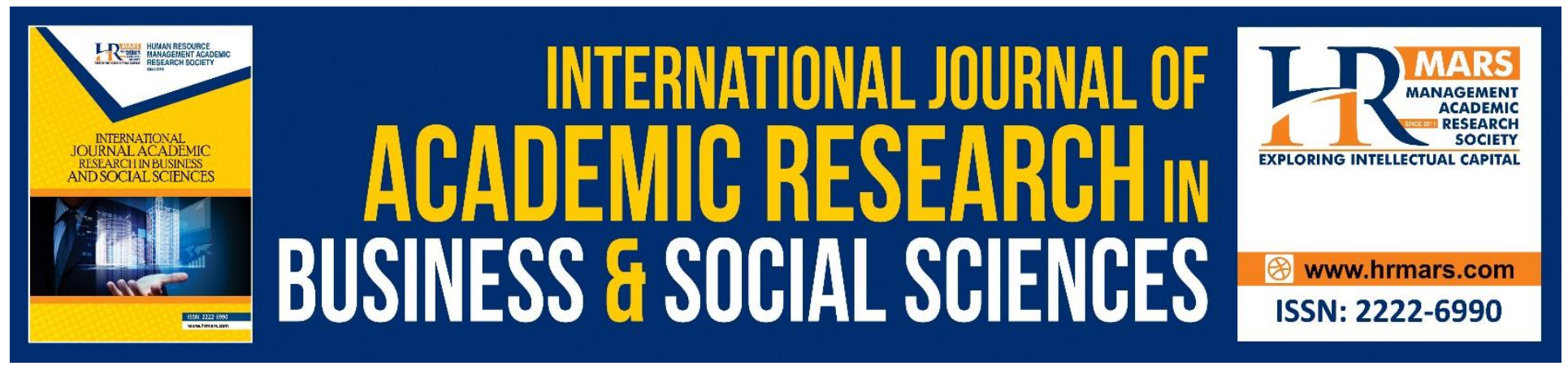

\title{
Influences of Knowledge Sharing in Improving Facilities Management Performance of Private Finance Initiative Projects
}

\author{
Irwan Mohammad Ali, Mohd Azian Zaidi, Kharizam Ismail, Mohamed Imran \\ Mohamed Ariff
}

To Link this Article: http://dx.doi.org/10.6007/IJARBSS/v9-i2/5655

DOI: $\quad 10.6007 /$ IJARBSS/v9-i2/5655

Received: 02 Feb 2019, Revised: 17 Feb 2019, Accepted: 30 Feb 2019

Published Online: 03 March 2019

In-Text Citation: (Ali, Zaidi, Ismail, \& Ariff, 2019)

To Cite this Article: Ali, I. M., Zaidi, M. A., Ismail, K., \& Ariff, M. I. M. (2019). Influences of Knowledge Sharing in Improving Facilities Management Performance of Private Finance Initiative Projects. International Journal of Academic Research in Business and Social Sciences, 9(2), 971-988.

Copyright: (C) 2019 The Author(s)

Published by Human Resource Management Academic Research Society (www.hrmars.com)

This article is published under the Creative Commons Attribution (CC BY 4.0) license. Anyone may reproduce, distribute, translate and create derivative works of this article (for both commercial and non-commercial purposes), subject to full attribution to the original publication and authors. The full terms of this license may be seen at: http://creativecommons.org/licences/by/4.0/legalcode

\section{Vol. 9, No. 2, 2019, Pg. 971 - 988}

Full Terms \& Conditions of access and use can be found at http://hrmars.com/index.php/pages/detail/publication-ethics 


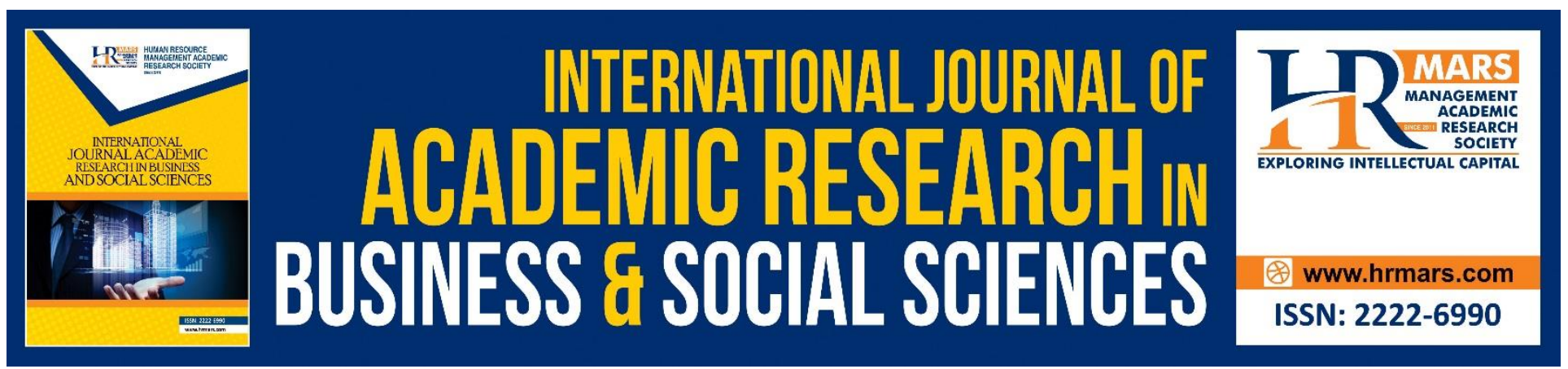

\title{
Influences of Knowledge Sharing in Improving Facilities Management Performance of Private Finance Initiative Projects
}

\author{
Irwan Mohammad Ali ${ }^{1}$, Mohd Azian Zaidi ${ }^{1}$, Kharizam Ismail ${ }^{1}$, \\ Mohamed Imran Mohamed Ariff ${ }^{2}$ \\ ${ }^{1}$ Faculty of Architecture, Planning and Surveying, Universiti Teknologi MARA, Perak Branch, Seri \\ Iskandar Campus, Seri Iskandar, 32610 Perak, Malaysia. \\ ${ }^{2}$ Faculty of Computer and Mathematical Sciences, Universiti Teknologi MARA, Perak Branch, \\ Tapah Campus, Tapah Road, 35400 Perak, Malaysia.
}

\begin{abstract}
Managing organization performance is very important in supply chain management. The situation is more critical in delivering public demands to develop and supply new facilities under Private Finance Initiative (PFI) projects. Thus, numerous issues and problems occurs in PFI projects that can affect the performance of Facilities Management (FM) phase has been highlighted by many researchers repetitively. This cross-sectional research aims are to discovers the influences of Knowledge Sharing (KS) in improving performance of PFI projects at FM phase. A set of questionnaires was developed and distributed to 151 respondents who is directly involve as practitioners in PFI-FM projects. However, only 111 responses were analysed using the SmartPLS 3.0 software. The finding shows that working culture (WC), staff attitude (SA), motivation to share (MV) and opportunities to share (OP) has significant influences with KS towards performance of PFI projects at FM phase. Meanwhile, nature of knowledge to share (NK) not significantly influences KS in PFI-FM projects.
\end{abstract}

Keywords: Knowledge Sharing, Facilities Management, Private Finance Initiative, Projects, Performance

\section{Introduction}

Managing organization performance is the key to success in business. Therefore, it is important to ensure that all members in the organization aware to its vision, mission and goals (Bryson, 2018). Good management practices in PFI project is very important to ensure the performance of the project is based on the value of money reimbursed by the government (Doherty, Horne, Wootton, Horne, \& Wootton, 2014; Gatti, 2013; Zhang \& Chen, 2013). If the performance of the project is not comprehensive monitored, this will upset the spending of public money. Generally, PFI projects is 
INTERNATIONAL JOURNAL OF ACADEMIC RESEARCH IN BUSINESS AND SOCIAL SCIENCES Vol. 9, No. 2, Feb, 2019, E-ISSN: 2222-6990 C 2019 HRMARS

very complicated for those still new in this method of deliver public project (Zou, Kumaraswamy, Chung, \& Wong, 2014). Previous research shows that there are numerous issues and problems highlighted constantly (Bing, Akintoye, Edwards, \& Hardcastle, 2005; Mu, Jong, \& Koppenjan, 2011). Among the related issues are related to the operational performance, defects management, difficulties to understand Key Performance Indicator (KPI), payment mechanism, value for money and the complexity of FM tasks.

The case is more complicated when this type of projects come to service delivery and facilities management stage (Bing et al., 2005). If the stated issues are not addressed properly, it may disrupt the overall performance of the project. This is because at this stage, the facilities management must be conducted according to the standards that has been set for the agreed period of time. Generally, the concession period of FM -PFI is about 20-30 years. There is a study conducted to show that knowledge sharing approach can contribute to improving organizational performance (Hartono \& Sheng, 2016). Based on previous studies and workshops carried out by authors, a conceptual model was developed. The development of this model is to measure the influence of each related factor. Thus, the main aims of this paper are to discovers the influences of knowledge sharing in improving FM performance of PFI projects.

\section{Research Conceptual Framework}

Based on Figure 1 below, it shows the conceptual framework for this research. This conceptual framework was described in the relations between determinant factors with the knowledge sharing towards performance management. In this study, the conceptual model is developed based on 22 items which are grouped into five determinant factors group namely Working Culture (WC), Staff Attitude (SA), Motivation (MV), Nature of Knowledge to Share (NK) and Opportunities to Share (OP). The determinant factors and each item are labelled with oval shape and rectangular shaped respectively.

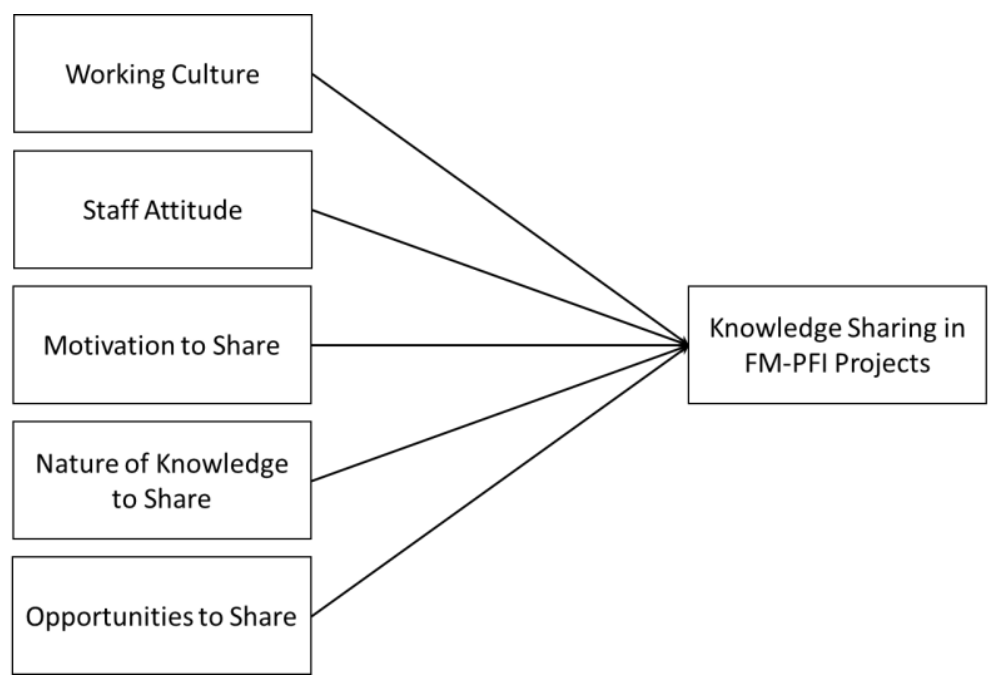

Figure 1. Research Conceptual Framework 
INTERNATIONAL JOURNAL OF ACADEMIC RESEARCH IN BUSINESS AND SOCIAL SCIENCES

Vol. 9, No. 2, Feb, 2019, E-ISSN: 2222-6990 C 2019 HRMARS

\section{Working Culture}

Commonly, working culture is the thought that generates values and beliefs in the organization. This progression naturally embraces of beliefs, thought processes, values and expanded from the attitude of personnel (Hofstede, 1983; Pettigrew, 1979; Schein, 2010). Previous research found that there are several factors that can contributes in emerging valuable working culture in the organization. The characteristics for working culture are tendency to be fairness with others (Connell, Ferres, \& Travaglione, 2003; Sholihin, Pike, Mangena, \& Li, 2011; Williamson \& Williams, 2011), bringing organization creativity to high level (Bendell, 2006; DiLiello \& Houghton, 2006; Martins \& Terblanche, 2003), responsive to the organization vision and mission (Collins \& Porras, 1991; Jovanovic, 2011; van Riel \& Balmer, 1997), stimulating and tolerant with diversity (Janssens \& Steyaert, 2003; Silverberg, Dosi, \& Orsenigo, 1988), enlightening social ties with others (Chambers, 2006; Fliaster \& Spiess, 2008; Wang, Ashleigh, \& Meyer, 2006), the effect of inclusive team characteristics (Ng, 1980; Tranfield, Smith, Foster, Wilson, \& Ivor Parry, 2000; Yeo, 2002), and innovation culture within the organization (Martins \& Terblanche, 2003; Nooteboom, 1999; Silverberg et al., 1988).

\section{Staff Attitude}

Staff attitude is a major consent to confirm that they are participate in improving the organization performance. In general, attitude is described as psychological or emotional condition of concentration, the probability dimension, a belief can transform individually (Davidson, 2013; Eagly \& Chaiken, 2007; Fishbein \& Raven, 1962). In every organization, staffs can have either an optimistic or bad attitude. This attitude will influence on specific work activities, services delivery, groups or management. For example, staff with bad attitudes normally not focus to daily tasks (Ross \& Goldner, 2009; Vakola \& Nikolaou, 2005). In this study, the characters of Staff Attitude consists of openness mindset (Levy, Beechler, Taylor, \& Boyacigiller, 2007; Story \& Barbuto, 2011), feel enjoy to helping others (Lin, 2007; McLure Wasko \& Faraj, 2005; Wright \& Pandey, 2008), voluntary mentoring new staff (Weng et al., 2010), senses of responsibility to organization (Gilman, 1999; Lindkvist \& Llewellyn, 2003), being proactive (Parker, Bindl, \& Strauss, 2010; Strauss, Griffin, \& Rafferty, 2009), and loyalty to the organization management (Schrag, 2001).

\section{Motivation to Share}

Fundamentally, motivation is the major forces to drive persons towards actions, desires and needs. Thus, motivation also has significant role in influencing individual to share their knowledge to others. This study explores that motivation has amounts of characters to look thoroughly. The characters for motivation to share consists of rewards and recognition to the employees (Iqbal, 2015; Kasim, 2015), sense of belonging and trust among employees (Keh \& Xie, 2009; Zhao, Lu, Wang, Chau, \& Zhang, 2012), providing training and development for the staffs (Scott \& Nelson, 1999; Shen \& Darby, 2006), reciprocity of knowledge, management support and job satisfaction (Ipe, 2003; Tamjidyamcholo, Bin Baba, Tamjid, \& Gholipour, 2013). 


\section{Nature of Knowledge to Share}

The important of knowledge is the nature of knowledge itself. This philosophy also known as epistemology where the justification of the nature and human knowledge (Audi, 2010; Hughes, Sharrock, \& Sharrock, 2016). This phenomenon has been ascertaining from the earliest times. In this study, the main focus is the availability and accessibility of the knowledge. Among the characters for nature of knowledge to share consists of value of the knowledge (Ipe, 2003), either it is tacit and explicit knowledge (Nonaka \& Takeuchi, 1995), access and benchmarking to the knowledge, and quality of the knowledge (Maier \& Hadrich, 2006; Syed-Ikhsan \& Rowland, 2004).

\section{Opportunities to Share}

Before sharing the knowledge, there must be opportunities that can accepted the process. Therefore, opportunities to share also plays an important role in sharing existing knowledge. In this study, the characters of opportunities to share consists of by knowing knowledge as power (Ipe, 2003; Marglin, 1984), technology and infrastructure are well established (Issa \& Haddad, 2008; Neches et al., 1991), allocation of specific time, knowledge self-efficacy among organization members (Hsu, Ju, Yen, \& Chang, 2007; Nonaka, Toyama, \& Nagata, 2000), system quality and communication skills (Cabrera \& Cabrera, 2005; de Vries, Bakker-Pieper, \& Oostenveld, 2010).

\section{Methodology}

The main objective of the study is to examine the relationship between identified determinant factors of individual beliefs towards knowledge sharing in Facilities Management of Higher Learning Institution under Private Finance Initiative projects. Also, simultaneously proposed the research structural model. The analysis was conducted using Structural Equation Modelling approach. Therefore, PLS-SEM software was applied to analyses the data. The analysis was carried out in two stages: the measurement model analysis and the structural model analysis. The measurement model assessment involved an examination of the adequacy of the scales by analyzing the relationships between each determinant factors and items. In contrast, the examination of the structural model focuses on testing the causal paths between the determinant factors and knowledge sharing towards performance management of Facilities Management of Higher Learning Institution under Private Finance Initiative projects.

\section{Results}

The main objective of the study is to identify the influences of knowledge sharing in improving performance of Private Finance Initiative projects at Facilities Management phase. The results on the analysis for the research objective were explained below. In order to achieve the research objective, respondents who directly involved in facilities management under private finance initiative projects were identified and invited to take part in this survey. Frequency descriptive analysis was carried out to obtain background information of the respondents who answered the questionnaires. Background information on respondents who answered the questionnaire consists of several categories, gender, age, academic qualification, position in the FM organization, and experiences of the respondents in FM-PFI projects. 
INTERNATIONAL JOURNAL OF ACADEMIC RESEARCH IN BUSINESS AND SOCIAL SCIENCES Vol. 9, No. 2, Feb, 2019, E-ISSN: $2222-6990$ ๑ 2019 HRMARS

A total of 151 questionnaires were distributed via web-based self-administrative questionnaire. Out of 151 questionnaires distributed, only 114 responses were recorded and completed. Apart from the questionnaire survey there are 2 reverse questions included to increase confident level on the responses. Further evaluation on the responses, only 111 responses were considered valid for analysis and 3 responses were rejected for negative response on reverse questions. Therefore, responses rate for this survey is 74 percent which is considered high responses for small populations. Details of the total number of data acquisition and returned questionnaire is shown in Table 1.

The questionnaires were specifically answered by respondents from practitioners' who has participate in facilities management of higher learning institution under private finance initiative projects. The clear majority of the respondents have bachelor's degree with 45 respondents (40.5\%), followed by diploma with 37 respondents (33.3\%) and certificate with 29 respondents (26.1\%) as their highest educational qualification. In terms of position in organization, the highest responses are from Assistant Engineers (Civil / Electrical / Mechanical) with 44 respondents (39.6\%) and followed by Engineers (Civil / Electrical / Mechanical) with 30 respondents (27\%). Meanwhile, Facility Managers and Building Surveyors is considered medium with 15 respondents (13.5\%) and 11 respondents $(9.9 \%)$ respectively.

The lowest response is from Quantity Surveyor and Architects / Landscape Architects with 8 respondents $(7.2 \%)$ and 3 respondents $(2.7 \%)$ respectively. It is clearly reflecting the reality of organization hierarchy in facilities management of higher learning institution under private finance initiative projects where dominated by assistant engineers. Then, the respondent's experiences in facilities management were identified with the highest responses from respondents that have $3-5$ years experiences $(26.1 \%)$, followed by respondents with $6-8$ years experiences $(24.3 \%)$ and more than 10 years experiences $(22.5 \%)$. The lowest response is from respondents that have $9-10$ years experiences and less than 2 years experiences with 14.4 percent and 12.6 percent respectively.

Table 1. Overall data acquisition for data analysis

\begin{tabular}{|l|c|c|c|}
\hline & Frequency & Percent & Valid Percent \\
\hline Questionnaire distributed & 151 & 100 & 100 \\
\hline Questionnaire not answered & 37 & 25 & 25 \\
\hline Questionnaire answered & 114 & 75 & 75 \\
\hline Valid answer for analysis & 111 & 74 & 74 \\
\hline
\end{tabular}


INTERNATIONAL JOURNAL OF ACADEMIC RESEARCH IN BUSINESS AND SOCIAL SCIENCES

Vol. 9, No. 2, Feb, 2019, E-ISSN: $2222-6990$ ㄷ 2019 HRMARS

Table 2. The Demographic Profiles of the respondents

\begin{tabular}{|c|c|c|c|c|c|}
\hline & & Frequency & Percent & Valid Percent & $\begin{array}{c}\text { Cumulative } \\
\text { Percent }\end{array}$ \\
\hline \multirow[t]{3}{*}{ Gender } & Male & 80 & 72.1 & 72.1 & 72.1 \\
\hline & Female & 31 & 27.9 & 27.9 & 100.0 \\
\hline & Total & 111 & 100.0 & 100.0 & \\
\hline \multirow{5}{*}{ Age } & $21-30$ years old & 14 & 12.6 & 12.6 & 12.6 \\
\hline & $31-40$ years old & 65 & 58.6 & 58.6 & 71.2 \\
\hline & $41-50$ years old & 26 & 23.4 & 23.4 & 94.6 \\
\hline & $51-60$ years old & 6 & 5.4 & 5.4 & 100.0 \\
\hline & Total & 111 & 100.0 & 100.0 & \\
\hline \multirow{4}{*}{ Qualification } & Certificate & 29 & 26.1 & 26.1 & 26.1 \\
\hline & Diploma & 37 & 33.3 & 33.3 & 59.4 \\
\hline & Bachelor's Degree & 45 & 40.5 & 40.5 & 100.0 \\
\hline & Total & 111 & 100.0 & 100.0 & \\
\hline \multirow[t]{9}{*}{ Position } & Facility Manager & 15 & 13.5 & 13.5 & 13.5 \\
\hline & Building Surveyor & 11 & 9.9 & 9.9 & 23.4 \\
\hline & Quantity Surveyor & 8 & 7.2 & 7.2 & 30.6 \\
\hline & $\begin{array}{l}\text { Engineer (Civil / } \\
\text { Electrical / }\end{array}$ & 30 & 27.0 & 27.0 & 57.6 \\
\hline & Mechanical) & & & & \\
\hline & Architect / & 3 & 2.7 & 2.7 & 60.3 \\
\hline & $\begin{array}{l}\text { Landscape Architect } \\
\text { Assistant Engineer }\end{array}$ & & & & \\
\hline & (Civil / Electrical / & 44 & 39.6 & 39.6 & 100.0 \\
\hline & $\begin{array}{c}\text { Mechanical) } \\
\text { Total }\end{array}$ & 111 & 100.0 & 100.0 & \\
\hline \multirow{6}{*}{$\begin{array}{c}\text { FM } \\
\text { Experiences }\end{array}$} & Less than 2 years & 14 & 12.6 & 12.6 & 12.6 \\
\hline & $3-5$ years & 29 & 26.1 & 26.1 & 38.7 \\
\hline & $6-8$ years & 27 & 24.3 & 24.3 & 63.1 \\
\hline & $9-10$ years & 16 & 14.4 & 14.4 & 77.5 \\
\hline & More than 10 years & 25 & 22.5 & 22.5 & 100.0 \\
\hline & Total & 111 & 100.0 & 100.0 & \\
\hline \multirow{6}{*}{$\begin{array}{c}\text { PFI } \\
\text { Experiences }\end{array}$} & Less than 2 years & 59 & 53.2 & 53.2 & 53.2 \\
\hline & $3-5$ years & 43 & 38.7 & 38.7 & 91.9 \\
\hline & $6-8$ years & 2 & 1.8 & 1.8 & 93.7 \\
\hline & $9-10$ years & 4 & 3.6 & 3.6 & 97.3 \\
\hline & More than 10 years & 3 & 2.7 & 2.7 & 100.0 \\
\hline & Total & 111 & 100.0 & 100.0 & \\
\hline
\end{tabular}


INTERNATIONAL JOURNAL OF ACADEMIC RESEARCH IN BUSINESS AND SOCIAL SCIENCES

Vol. 9, No. 2, Feb, 2019, E-ISSN: 222 2-6990 (C) 2019 HRMARS

\section{Measurement Model Assessment}

The assessment of measurement is essential and necessary as it provides thorough testing for the reliability and validity of the scales. It is also employed to measure the latent constructs and their manifest variables (Loehlin, 1998). Several stages were used in the assessment of the measurement model. According to Henseler, Hubona and Ray (2016), they suggest four criterions of model assessment. These criterions comprise the assessment of indicator reliability; internal consistency reliability; convergent validity; and discriminant validity at indicator and construct levels.

\section{Convergent Validity}

Convergent validity specifies that items that are indicators of a construct should share a high proportion of variance (Hair, Black, Babin, \& Anderson, 2010). The convergent validity of the scale items was assessed using three criteria. First, the factor loadings should be greater than 0.50 as proposed by (Hair et al., 2010). Secondly, the composite reliability for each construct should exceed 0.70. Lastly, the Average variance extracted (AVE) for each construct should be above the recommended cut-off 0.50 (Fornell \& Larcker, 1981).

All loadings were greater than 0.40 , with most loadings exceeding 0.60 except loadings for the AVE. The factor loadings ranged from 0.501 to 0.963 . Items with loadings less than 0.70 can still be considered significant (Hair et al., 2010). The high factor loadings give reason to conclude that the measures have convergent validity. All constructs factor loading exceeded the 0.50 cut-off, with the exception of AVE.

Normally, the acceptable AVE threshold is 0.5 (Hair et al., 2010). But, for this research the AVE is less than 0.5 and considered as insufficient. According to Ping (2009) even if AVE is lower than 0.5 this is not fatal in testing of new model. Besides, not all scholars accept AVE as crucial to establish convergent validity. Low AVE at an initial stage of model testing should be viewed as exploratory and accepted until perfect observation is attained. Further, for some case AVE less than 0.5 is also can be acceptable (Fornell \& Larcker, 1981). Yet, every determinant factor was found to have adequate convergent validity based on their good composite reliability $(>0.60)$. As summary, based on results in Table 3 it shows that the study's measurement model has demonstrated an adequate convergent validity.

Table 2. Convergent Validity

\begin{tabular}{|l|c|c|c|}
\hline \multicolumn{1}{|c|}{ Determinant Factor } & AVE & Composite Reliability & $\begin{array}{c}\text { Cronbach's } \\
\text { Alpha }\end{array}$ \\
\hline Working Culture & 0.296471 & 0.654777 & 0.886339 \\
Staff Attitude & 0.294805 & 0.625691 & 0.858933 \\
Motivation to Share & 0.541381 & 0.746521 & 0.818055 \\
Nature of Knowledge to Share & 0.349878 & 0.556700 & 0.796649 \\
Opportunity to Share & 0.315885 & 0.623885 & 0.851403 \\
Knowledge Sharing & 0.392566 & 0.763010 & 0.924021 \\
\hline
\end{tabular}


INTERNATIONAL JOURNAL OF ACADEMIC RESEARCH IN BUSINESS AND SOCIAL SCIENCES

Vol. 9, No. 2, Feb, 2019, E-ISSN: 2222-6990 C 2019 HRMARS

\section{Discriminant Validity}

The next step in the construct validation process is the assessment of discriminant validity. Discriminant validity reflects the extent to which the measure is unique and not simply a reflection of other variables (Peter \& Churchill, 1986). Each dimension of a construct should be unique and different from the other even though each reflects a portion of that construct. There are several ways to evaluate discriminant validity. Average Variance Extracted (AVE) is a common method of testing discriminant validity (Anderson \& Gerbing, 1988). Discriminate validity was evaluated by examining the cross loadings of each item in the constructs and the square root of AVE calculated for each construct. All the items should have higher loading on their corresponding construct than the cross loadings on the other constructs in the model.

Table 3. Discriminate validity

\begin{tabular}{|l|l|l|l|l|l|l|l|}
\hline & AVE & $\begin{array}{c}\text { Workin } \\
\text { Culture }\end{array}$ & $\begin{array}{c}\text { Staff } \\
\text { Attitud } \\
\text { e }\end{array}$ & $\begin{array}{c}\text { Motivatio } \\
\text { n to Share }\end{array}$ & $\begin{array}{c}\text { Nature of } \\
\text { Knowledg } \\
\text { e to Share }\end{array}$ & $\begin{array}{c}\text { Opportunitie } \\
\text { s to Share }\end{array}$ & $\begin{array}{l}\text { Knowledg } \\
\text { e Sharing }\end{array}$ \\
\hline $\begin{array}{l}\text { Working } \\
\text { Culture }\end{array}$ & $\begin{array}{l}0.29647 \\
1\end{array}$ & $\mathbf{0 . 5 4 4 ^ { * }}$ & & & & & \\
\hline $\begin{array}{l}\text { Staff } \\
\text { Attitude }\end{array}$ & $\begin{array}{l}0.29480 \\
5\end{array}$ & & $\mathbf{0 . 5 4 3 *}$ & & & & \\
\hline $\begin{array}{l}\text { Motivation } \\
\text { to Share }\end{array}$ & $\begin{array}{l}0.54138 \\
1\end{array}$ & & & $\mathbf{0 . 7 1 3 *}$ & & & \\
\hline $\begin{array}{l}\text { Nature of } \\
\text { Knowledge } \\
\text { to Share }\end{array}$ & $\begin{array}{l}0.34987 \\
8\end{array}$ & & & & $\mathbf{0 . 5 8 8 ^ { * }}$ & & \\
\hline $\begin{array}{l}\text { Opportunitie } \\
\text { sto Share }\end{array}$ & $\begin{array}{l}0.31588 \\
5\end{array}$ & & & & & $\mathbf{0 . 5 6 0 *}$ & \\
\hline $\begin{array}{l}\text { Knowledge } \\
\text { Sharing }\end{array}$ & $\begin{array}{l}0.39256 \\
6\end{array}$ & & & & & & $\mathbf{0 . 6 2 6 *}$ \\
\hline
\end{tabular}

Note: *The values of diagonal AVE are greater than the off-diagonal AVE; where diagonal values present the AVE values.

\section{Structural Model Assessment}

The second assessment is structural model assessment. This is done when a reliability and validity of measurement model has been established. The structural model tests the relationship between the determinant factors and knowledge sharing with the help of a path diagram. There are two aspects of assessment in a structural model assessment which are (i) Explanatory Power; and (ii) Predictive Power. The criteria for Explanatory Power include Coefficient of Determination $\left(R^{2}\right)$ and the Effect Size $\left(f^{2}\right)$. Meanwhile, Predictive Power includes Path Coefficient $(\beta)$; Predictive Relevance $\left(Q^{2}\right)$; and Relative Impact $\left(q^{2}\right)$. 
INTERNATIONAL JOURNAL OF ACADEMIC RESEARCH IN BUSINESS AND SOCIAL SCIENCES

Vol. 9, No. 2, Feb, 2019, E-ISSN: 2222-6990 C 2019 HRMARS

\section{Predictive Power}

The next step is assessing the path coefficient of all determinant factors (paths) by comparing beta $(\beta)$ values among all the paths. The path coefficient represents the hypothesized relationships. The highest $\beta$ value indicates the strongest relationship of determinant factors (independent variables) towards Knowledge Sharing in FM- PFI projects (dependent variables). According to Hair, Sarstedt, Hopkins and Kuppelwieser (2014) it is suggested that path coefficients should exceed 0.10 to account for a certain impact within the model. However, $\beta$ value has to be tested for its significance level through t-value test. The test is carried out by performing a non-parametric bootstrapping technique (Chin, 1998).

In this research, bootstrap re-sampling method was employed to test the statistical significant of each path coefficient. The number of resample iterations is 5000 to generate a stable estimation as suggested by Henseler et al., (2016). According to Hair et al., (2014), it is suggested that acceptable t-values for a two-tailed test are 1.64 (significance level $=0.10$ or $10 \%$ ), 1.96 (significance level $=0.05$ or $5 \%$ ) and 2.58 (significance level $=0.01$ or 1\%). The bootstrapping result shown in Figure 2.

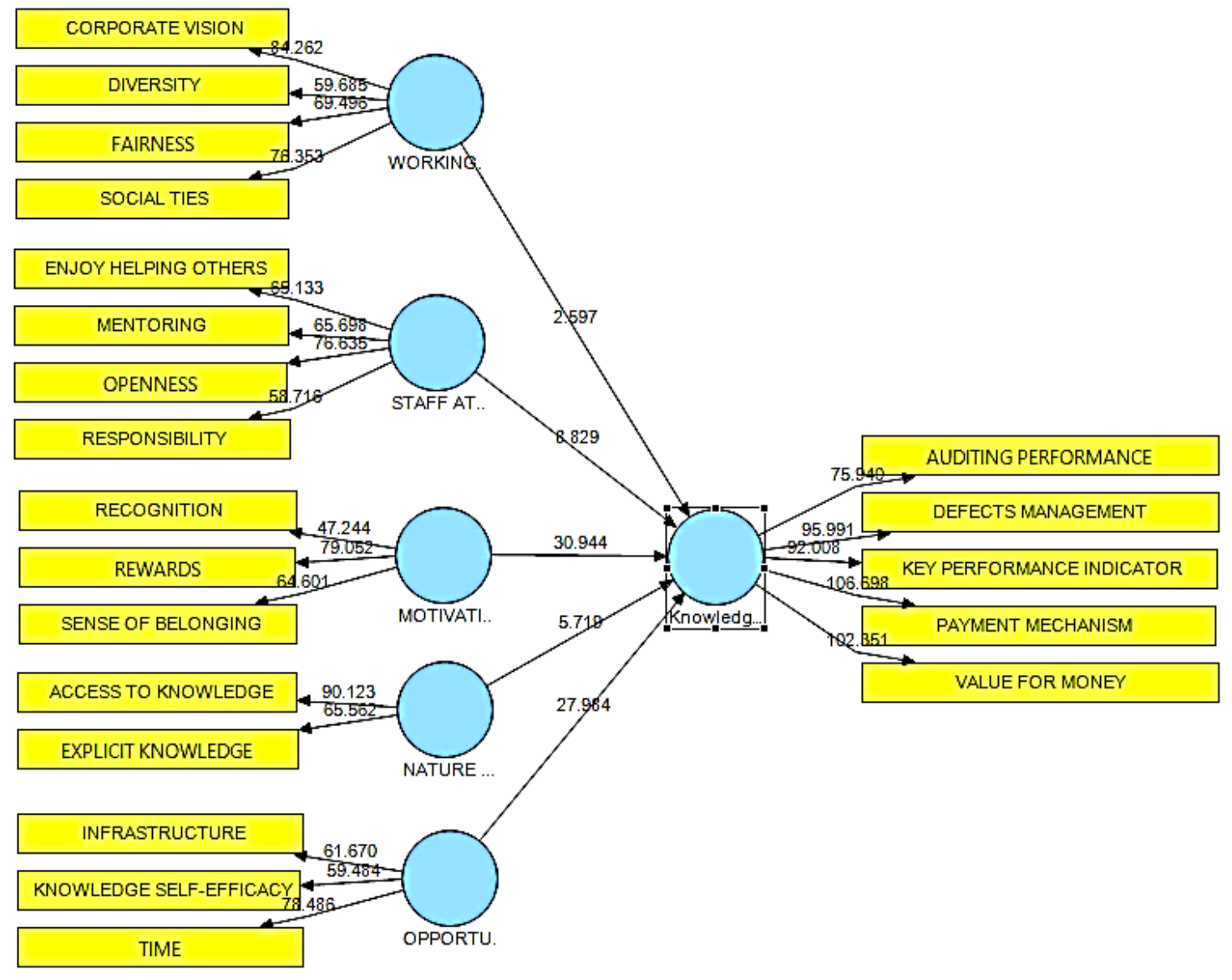

Figure 2. Bootstrapping analysis to predict power 
INTERNATIONAL JOURNAL OF ACADEMIC RESEARCH IN BUSINESS AND SOCIAL SCIENCES

Table 4. Results of hypothesis tests

\begin{tabular}{|c|l|c|c|c|}
\hline Hypothesis & \multicolumn{1}{|c|}{ Relationship } & $\begin{array}{c}\text { Path Coefficient } \\
\text { / } 8\end{array}$ & t-value & Remarks \\
\hline H1 & $\begin{array}{l}\text { Working Culture } \\
\text { Knowledge Sharing in FM-HLI-PFI } \\
\text { projects }\end{array}$ & 0.050 & $2.597^{* * *}$ & Significant \\
\hline H2 & $\begin{array}{l}\text { Staff Attitude } \\
\text { Knowledge Sharing in FM-HLI-PFI } \\
\text { projects }\end{array}$ & 0.173 & $8.829 * * *$ & Significant \\
\hline H3 & $\begin{array}{l}\text { Motivation to Share > } \\
\text { Knowledge Sharing in FM-HLI-PFI } \\
\text { projects }\end{array}$ & 0.433 & $30.944 * * *$ & Significant \\
\hline H4 & $\begin{array}{l}\text { Nature of Knowledge to Share > } \\
\text { Knowledge Sharing in FM-HLI-PFI } \\
\text { projects }\end{array}$ & -0.059 & $8.829 * * *$ & Sot \\
\hline H5 & $\begin{array}{l}\text { Opportunities to Share }> \\
\text { Knowledge Sharing in FM-HLI-PFI } \\
\text { projects }\end{array}$ & 0.348 & $27.984 * * *$ & Significant \\
\hline
\end{tabular}

Results from Table 5 show that the $\beta$ values attained are higher than the cut-off point value of 0.01 for working culture, staff attitude, motivation to share and opportunities to share as suggested by Hair et al., (2014). The highest $\beta$ value for determinant factor which has the most significant relationship with knowledge sharing are the motivation to share $(\beta=0.433)$ and followed by opportunities to share $(\beta=0.348)$. The next step is to discuss in detail on each hypothesis resulting from this analysis. The t-values are higher than minimum cut-off significance value which is at least 0.01 or $1 \%$. This indicates that Working Culture, Staff Attitude, Motivation to Share and Opportunities to Share factors have significant relationship. Meanwhile, only one factor (Nature of Knowledge) have insignificant relationship with knowledge sharing in Facilities Management of Private Finance Initiative Projects.

\section{Conclusion}

Based on finding from this research, from 5 hypotheses only 4 has significant influences on knowledge sharing in improving performance of private finance initiative projects at facilities management phase. It is found that the hypothesis for Nature of Knowledge is not accepted. The other hypotheses such as Working Culture, Staff Attitude, Motivation to Share and Opportunities to Share is accepted. It is suggested that longitudinal research approach to be conducted for future research. The aim is to study the effects of Knowledge Sharing after particular organization boost 
INTERNATIONAL JOURNAL OF ACADEMIC RESEARCH IN BUSINESS AND SOCIAL SCIENCES

Vol. 9, No. 2, Feb, 2019, E-ISSN: $2222-6990$ ๑ 2019 HRMARS

some incentive and encouragement towards performance management based on the 4 determinant factors.

\section{Acknowledgments}

This research is part of an ongoing PhD research at the Faculty of Architecture, Planning and Surveying, Universiti Teknologi MARA, Cawangan Perak and funded under Geran Insentif Khas Penyeliaan Perak. The authors would like to express their deepest gratitude to Faculty of Architecture, Planning and Surveying, and Universiti Teknologi MARA, Cawangan Perak.

\section{Corresponding Author}

Irwan Mohammad Ali, Faculty of Architecture, Planning and Surveying, Universiti Teknologi MARA, Perak Branch, Seri Iskandar Campus, Seri Iskandar, 32610 Perak, Malaysia.

Email: irwan9471@perak.uitm.edu.my / irwanmohdali@gmail.com

\section{References}

Anderson, J. C., \& Gerbing, D. W. (1988). Structural equation modeling in practice: A review and recommended two-step approach. Psychological Bulletin, 103(3), 411-423. https://doi.org/10.1037/0033-2909.103.3.411

Audi, R. (2010). Epistemology. Routledge. https://doi.org/10.4324/9780203846469

Bendell, T. (2006). A review and comparison of six sigma and the lean organizations. The TQM Magazine, 18(3), 255-262. https://doi.org/10.1108/09544780610659989

Bing, L., Akintoye, A., Edwards, P. J., \& Hardcastle, C. (2005). The allocation of risk in PPP/PFI construction projects in the UK. International Journal of Project Management, 23(1), 25-35. https://doi.org/10.1016/J.IJPROMAN.2004.04.006

Bryson, J. M. (John M. (2018). Strategic planning for public and nonprofit organizations : a guide to strengthening and sustaining organizational achievement. Wiley Publisher.

Cabrera, E. F., \& Cabrera, A. (2005). Fostering knowledge sharing through people management practices. The International Journal of Human Resource Management, 16(5), 720-735. https://doi.org/10.1080/09585190500083020

Chambers, D. (2006). New Social Ties. London: Palgrave Macmillan UK. https://doi.org/10.1057/9780230627284

Chin, W. W. (1998). Commentary: Issues and Opinion on Structural Equation Modeling. MIS Quarterly. Management Information Systems Research Center, University of Minnesota. https://doi.org/10.2307/249674

Collins, J. C., \& Porras, J. I. (1991). Organizational Vision and Visionary Organizations. California Management Review, 34(1), 30-52. https://doi.org/10.2307/41166682

Connell, J., Ferres, N., \& Travaglione, T. (2003). Engendering trust in manager-subordinate relationships. Personnel Review, 32(5), 569-587. https://doi.org/10.1108/00483480310488342

Davidson, D. (2013). Knowing One's Own Mind. In The American Philosophical Association Centennial Series (pp. 389-409). https://doi.org/10.5840/apapa2013158

de Vries, R. E., Bakker-Pieper, A., \& Oostenveld, W. (2010). Leadership = Communication? The Relations of Leaders' Communication Styles with Leadership Styles, Knowledge Sharing and 
INTERNATIONAL JOURNAL OF ACADEMIC RESEARCH IN BUSINESS AND SOCIAL SCIENCES

Vol. 9, No. 2, Feb, 2019, E-ISSN: $2222-6990$ ๑ 2019 HRMARS

Leadership Outcomes. Journal of Business and Psychology, 25(3), 367-380. https://doi.org/10.1007/s10869-009-9140-2

DiLiello, T. C., \& Houghton, J. D. (2006). Maximizing organizational leadership capacity for the future. $\begin{array}{llll}\text { Journal of } & \text { Managerial 21(4), }\end{array}$ https://doi.org/10.1108/02683940610663114

Doherty, T. L., Horne, T., Wootton, S., Horne, T., \& Wootton, S. (2014). Managing Public Services Implementing Changes. Routledge. https://doi.org/10.4324/9781315887432

Eagly, A. H., \& Chaiken, S. (2007). The Advantages of an Inclusive Definition of Attitude. Social Cognition, 25(5), 582-602. https://doi.org/10.1521/soco.2007.25.5.582

F. Hair Jr, J., Sarstedt, M., Hopkins, L., \& G. Kuppelwieser, V. (2014). Partial least squares structural equation modeling (PLS-SEM). European Business Review, 26(2), 106-121. https://doi.org/10.1108/EBR-10-2013-0128

Fishbein, M., \& Raven, B. H. (1962). The AB Scales. Human Relations, 15(1), 35-44. https://doi.org/10.1177/001872676201500104

Fliaster, A., \& Spiess, J. (2008). Knowledge Mobilization through Social Ties: The Cost-Benefit Analysis. Schmalenbach Business Review, 60(1), 99-117. https://doi.org/10.1007/BF03396761

Fornell, C., \& Larcker, D. F. (1981). Evaluating Structural Equation Models with Unobservable Variables and Measurement Error. Journal of Marketing Research, 18(1), 39. https://doi.org/10.2307/3151312

Gatti, S. (2013). Project Finance in Theory and Practice: Designing, Structuring, and Financing Private and Public Projects. Elsevier Ltd.

Gilman, S. (1999). The Quest for Responsibility: Accountability and Citizenship in Complex Organizations. Administrative Theory \& Praxis, 21(2), 233-235. https://doi.org/10.1080/10841806.1999.11643368

Hair, J. F., Black, W. C., Babin, B. J., \& Anderson, R. E. (2010). Multivariate Data Analysis. Pearson.

Hartono, R., \& Sheng, M. L. (2016). Knowledge sharing and firm performance: the role of social networking site and innovation capability. Technology Analysis \& Strategic Management, 28(3), 335-347. https://doi.org/10.1080/09537325.2015.1095289

Henseler, J., Hubona, G., \& Ray, P. A. (2016). Using PLS path modeling in new technology research: updated guidelines. Industrial Management \& Data Systems, 116(1), 2-20. https://doi.org/10.1108/IMDS-09-2015-0382

Hofstede, G. (1983). The Cultural Relativity of Organizational Practices and Theories. Journal of International Business Studies, 14(2), 75-89. https://doi.org/10.1057/palgrave.jibs.8490867

Hsu, M.-H., Ju, T. L., Yen, C.-H., \& Chang, C.-M. (2007). Knowledge sharing behavior in virtual communities: The relationship between trust, self-efficacy, and outcome expectations. International Journal of Human-Computer Studies, 65(2), 153-169. https://doi.org/10.1016/J.IJHCS.2006.09.003

Hughes, J. A., Sharrock, W. W., \& Sharrock, W. W. (2016). The Philosophy of Social Research. Routledge. https://doi.org/10.4324/9781315840710

Ipe, M. (2003). Knowledge Sharing in Organizations: A Conceptual Framework. Human Resource Development Review, 2(4), 337-359. https://doi.org/10.1177/1534484303257985

Iqbal, S. (2015). Employees' perceptions of human resource management practices and knowledge 
INTERNATIONAL JOURNAL OF ACADEMIC RESEARCH IN BUSINESS AND SOCIAL SCIENCES

Vol. 9, No. 2, Feb, 2019, E-ISSN: $2222-6990$ ๑ 2019 HRMARS

sharing behaviour. Massey University. Retrieved from https://mro.massey.ac.nz/bitstream/handle/10179/6788/02_whole.pdf

Issa, R. R. A., \& Haddad, J. (2008). Perceptions of the impacts of organizational culture and information technology on knowledge sharing in construction. Construction Innovation, 8(3), 182-201. https://doi.org/10.1108/14714170810888958

Janssens, M., \& Steyaert, C. (2003). Theories of Diversity within Organization Studies: Debates and Future Trajectories. SSRN Electronic Journal. https://doi.org/10.2139/ssrn.389044

Jovanovic, J. (2011). Management of The Organization Based on Balanced Scorecards. International Journal for Quality (Vol. 5). Retrieved from http://www.ijqr.net/journal/v5-n4/9.pdf

Kasim, H. A. (2015). Antecedents of Knowledge Sharing Behavior - Analyzing the Influence of Performance Expectancy and User's Attitude www.globalbizresearch.org. International Journal of Recent Advances in Organizational Behaviour and Decision Sciences (IJRAOB) An Online International Research Journal, 1(3), 2311-3197. Retrieved from http://globalbizresearch.org/files/5036_ijraob_hairol-adenan-kasim-178576.pdf

Keh, H. T., \& Xie, Y. (2009). Corporate reputation and customer behavioral intentions: The roles of trust, identification and commitment. Industrial Marketing Management, 38(7), 732-742. https://doi.org/10.1016/J.INDMARMAN.2008.02.005

Levy, O., Beechler, S., Taylor, S., \& Boyacigiller, N. A. (2007). What we talk about when we talk about 'global mindset': Managerial cognition in multinational corporations. Journal of International Business Studies, 38(2), 231-258. https://doi.org/10.1057/palgrave.jibs.8400265

Lin, H.-F. (2007). Effects of extrinsic and intrinsic motivation on employee knowledge sharing intentions. Journal of Information Science, 33(2), 135-149. https://doi.org/10.1177/0165551506068174

Lindkvist, L., \& Llewellyn, S. (2003). Accountability, responsibility and organization. Scandinavian Journal of Management, 19(2), 251-273. https://doi.org/10.1016/S0956-5221(02)00027-1

Loehlin, J. C. (1998). Latent variable models: An introduction to factor, path, and structural analysis. Lawrence Erlbaum Associates Publishers. Retrieved from http://psycnet.apa.org/record/199807069-000

Maier, R., \& Hadrich, T. (2006). Knowledge Management Systems. In Encyclopedia of Knowledge Management (pp. 442-450). IGI Global. https://doi.org/10.4018/978-1-59140-573-3.ch058

Marglin, S. A. (1984). Knowledge and Power. In Firms, Organization and Labour (pp. 146-164). London: Palgrave Macmillan UK. https://doi.org/10.1007/978-1-349-06663-6_9

Martins, E. C., \& Terblanche, F. (2003). Building organizational culture that stimulates creativity and innovation. European Journal of Innovation Management, 6(1), 64-74. https://doi.org/10.1108/14601060310456337

McLure Wasko, M., \& Faraj, S. (2005). Why Should I Share? Examining Social Capital and Knowledge Contribution in Electronic Networks of Practice. Retrieved from https://pdfs.semanticscholar.org/3668/fd3eacef038872aa60124737a50d4968ff79.pdf

Mu, R., Jong, M. de, \& Koppenjan, J. (2011). The rise and fall of Public-Private Partnerships in China: a path-dependent approach. Journal of Transport Geography, 19(4), 794-806. https://doi.org/10.1016/J.JTRANGEO.2010.10.002

Neches, R., Fikes, R. E., Finin, T., Gruber, T., Patil, R., Senator, T., \& Swartout, W. R. (1991). Enabling 
INTERNATIONAL JOURNAL OF ACADEMIC RESEARCH IN BUSINESS AND SOCIAL SCIENCES

Vol. 9, No. 2, Feb, 2019, E-ISSN: $2222-6990$ ๑ 2019 HRMARS

Technology for Knowledge Sharing. Al Magazine, 12(3), 36-36. https://doi.org/10.1609/AIMAG.V1213.902

$\mathrm{Ng}$, P. T. (1980). Human systems management. Human Systems Management (Vol. 23). NorthHolland. Retrieved from https://content.iospress.com/articles/human-systemsmanagement/hsm550

Nonaka, I., \& Takeuchi, H. (1995). The Knowledge-creating Company: How Japanese Companies Create the Dynamics of Innovation. Oxford University Press.

Nonaka, I., Toyama, R., \& Nagata, A. (2000). A firm as a knowledge-creating entity: a new perspective on the theory of the firm. Industrial and Corporate Change, 9(1), 1-20. https://doi.org/10.1093/icc/9.1.1

Nooteboom, B. (1999). Innovation, learning and industrial organization. Cambridge Journal of Economics, 23(2), 127-150. https://doi.org/10.1093/cje/23.2.127

Parker, S. K., Bindl, U. K., \& Strauss, K. (2010). Making Things Happen: A Model of Proactive $\begin{array}{llll}\text { Motivation. Journal of } & \text { 36(4), }\end{array}$ https://doi.org/10.1177/0149206310363732

Peter, J. P., \& Churchill, G. A. (1986). Relationships among Research Design Choices and Psychometric Properties of Rating Scales: A Meta-Analysis. Journal of Marketing Research, 23(1), 1. https://doi.org/10.2307/3151771

Pettigrew, A. M. (1979). On Studying Organizational Cultures. Administrative Science Quarterly, 24(4), 570. https://doi.org/10.2307/2392363

Ping, R. A. (2009). Is there any way to improve Average Variance Extracted (AVE) in a Latent Variable (LV) X (Revised)? Retrieved from http://www.wright.edu/ robert.ping/ImprovAVE2.doc)

Ross, C. A., \& Goldner, E. M. (2009). Stigma, negative attitudes and discrimination towards mental illness within the nursing profession: a review of the literature. Journal of Psychiatric and Mental Health Nursing, 16(6), 558-567. https://doi.org/10.1111/j.1365-2850.2009.01399.x

Schein, E. H. (2010). Organizational culture and leadership. Jossey-Bass.

Schrag, B. (2001). The Moral Significance of Employee Loyalty. Business Ethics Quarterly, 11(1), 41. https://doi.org/10.2307/3857868

Scott, T. M., \& Nelson, C. M. (1999). Functional Behavioral Assessment: Implications for Training and Staff Development. Behavioral Disorders, 249-252. https://doi.org/10.1177/019874299902400308

Shen, J., \& Darby, R. (2006). Training and management development in Chinese multinational enterprises. Employee Relations, 28(4), 342-362. https://doi.org/10.1108/01425450610673402

Sholihin, M., Pike, R., Mangena, M., \& Li, J. (2011). Goal-setting participation and goal commitment: Examining the mediating roles of procedural fairness and interpersonal trust in a UK financial services organization. The British Accounting Review, 43(2), 135-146. https://doi.org/10.1016/J.BAR.2011.02.003

Silverberg, G., Dosi, G., \& Orsenigo, L. (1988). Innovation, Diversity and Diffusion: A Self-Organization Model. The Economic Journal, 98(393), 1032. https://doi.org/10.2307/2233718

Story, J. S. P., \& Barbuto, J. E. (2011). Global Mindset: A Construct Clarification and Framework. Journal of Leadership \& Organizational Studies, 18(3), 377-384. https://doi.org/10.1177/1548051811404421 
INTERNATIONAL JOURNAL OF ACADEMIC RESEARCH IN BUSINESS AND SOCIAL SCIENCES

Vol. 9, No. 2, Feb, 2019, E-ISSN: $2222-6990$ ๑ 2019 HRMARS

Strauss, K., Griffin, M. A., \& Rafferty, A. E. (2009). Proactivity Directed Toward the Team and Organization: The Role of Leadership, Commitment and Role-breadth Self-efficacy. British Journal of Management, 20(3), 279-291. https://doi.org/10.1111/j.1467-8551.2008.00590.x

Syed-Ikhsan, S. O. S., \& Rowland, F. (2004). Benchmarking knowledge management in a public organization in Malaysia. Benchmarking: An International Journal, 11(3), 238-266. https://doi.org/10.1108/14635770410538745

Tamjidyamcholo, A., Bin Baba, M. S., Tamjid, H., \& Gholipour, R. (2013). Information security Professional perceptions of knowledge-sharing intention under self-efficacy, trust, reciprocity, and shared-language. Computers \& Education, 68, 223-232. https://doi.org/10.1016/J.COMPEDU.2013.05.010

Tranfield, D., Smith, S., Foster, M., Wilson, S., \& Ivor Parry. (2000). Strategies for managing the teamworking agenda: Developing a methodology for team-based organization. International Journal of Production Economics, 65(1), 33-42. https://doi.org/10.1016/S0925-5273(99)000882

Vakola, M., \& Nikolaou, I. (2005). Attitudes towards organizational change. Employee Relations, 27(2), 160-174. https://doi.org/10.1108/01425450510572685

van Riel, C. B. M., \& Balmer, J. M. T. (1997). Corporate identity: the concept, its measurement and management. European Journal of Marketing, 31(5/6), 340-355. https://doi.org/10.1108/eb060635

Wang, J.-K., Ashleigh, M., \& Meyer, E. (2006). Knowledge sharing and team trustworthiness: it's all about social ties! Knowledge Management Research \& Practice, 4(3), 175-186. https://doi.org/10.1057/palgrave.kmrp.8500098

Weng, R.-H., Huang, C.-Y., Tsai, W.-C., Chang, L.-Y., Lin, S.-E., \& Lee, M.-Y. (2010). Exploring the impact of mentoring functions on job satisfaction and organizational commitment of new staff nurses. BMC Health Services Research, 10(1), 240. https://doi.org/10.1186/1472-6963-10-240

Williamson, K., \& Williams, K. J. (2011). Organizational justice, trust and perceptions of fairness in the implementation of agenda for change. Radiography, 17(1), 61-66. https://doi.org/10.1016/J.RADI.2010.08.004

Wright, B. E., \& Pandey, S. K. (2008). Public Service Motivation and the Assumption of PersonOrganization Fit. Administration \& Society, 40(5), 502-521. https://doi.org/10.1177/0095399708320187

Yeo, R. (2002). From individual to team learning: practical perspectives on the learning organization. Team Performance Management: An International Journal, 8(7/8), 157-170. https://doi.org/10.1108/13527590210442221

Zhang, X., \& Chen, S. (2013). A systematic framework for infrastructure development through public private partnerships. IATSS Research, 36(2), 88-97. https://doi.org/10.1016/J.IATSSR.2012.11.001

Zhao, L., Lu, Y., Wang, B., Chau, P. Y. K., \& Zhang, L. (2012). Cultivating the sense of belonging and motivating user participation in virtual communities: A social capital perspective. International Journal of Information Management, 32(6), 574-588. https://doi.org/10.1016/J.IJINFOMGT.2012.02.006

Zou, W., Kumaraswamy, M., Chung, J., \& Wong, J. (2014). Identifying the critical success factors for 
INTERNATIONAL JOURNAL OF ACADEMIC RESEARCH IN BUSINESS AND SOCIAL SCIENCES

Vol. 9, No. 2, Feb, 2019, E-ISSN: 2222-6990 @ 2019 HRMARS

relationship management in PPP projects. International Journal of Project Management, 32(2), 265-274. https://doi.org/10.1016/J.IJPROMAN.2013.05.004 